\title{
Factors Affecting Opposition of Insulin Initiation among Type 2 DM Patients at Ain Shams University Hospitals
}

\author{
Eman M. Ahmed ${ }^{1}$, Maha M. Wahdan ${ }^{2 *}$, Essam M. Bayoumy ${ }^{3}$, Diaa Marzouk ${ }^{1}$ \\ ${ }^{1}$ Family Medicine Department, Faculty of Medicine, Ain Shams University, Cairo, Egypt \\ ${ }^{2}$ Community, Environmental and Occupational Medicine Department, Faculty of Medicine, Ain Shams \\ University, Cairo, Egypt \\ ${ }^{3}$ Internal Medicine Department, Faculty of Medicine, Ain Shams University, Cairo, Egypt
}

\begin{abstract}
:
Background: One of the obstacles to diabetes management is delayed insulin initiation in uncontrolled type 2DM patients. Objectives: To measure the frequency of insulin opposition among Egyptian type 2 diabetes patients, uncontrolled, on two or more oral hypoglycemic combination therapy and to assess factors associated with insulin opposition. Methods: Cross-sectional study was conducted in outpatient clinics at Ain Shams University hospitals, on purposive sample of 103 type 2 diabetic patients, uncontrolled, on two or more oral hypoglycemic combination therapy, using a structured questionnaire. Results: Uncontrolled type 2DM patients opposed to start insulin were 55.3\%. The most common negative attitudes that differ significantly between insulin opposers and acceptors were: insulin as last resort $(77.2 \%$ vs $50 \%)$, perceived diabetes severity $(75.4 \%$ vs $63 \%)$, concerns about less flexibility (59.6 \%vs 52.2\%), time and effort with insulin injections $(29.8 \%$ vs $13 \%)$ and expected harm from insulin (28.1\% vs $13 \%$ ). Opposers had significantly less agreement on positive items regarding the role of insulin in improving energy level (22.8\% vs 50\%), improving health (28.1\% vs $60.9 \%)$, and preventing complications of diabetes (42.1\% vs $67.4 \%)$. Conclusion and recommendations: high rate of insulin opposition among uncontrolled type 2DM and its associated factors among T2DM patients, therefore, the need for increasing physicians' awareness through training sessions is important to improve the strategy for identifying and reducing insulin opposition among patients.
\end{abstract}

Keywords: Insulin, Opposition, Type 2DM

\section{Introduction:}

Diabetes mellitus is one of the largest global health emergencies of the 21 st century. ${ }^{(1)}$ Among the top ten countries for number of diabetics aged 20-79 years, Egypt ranks the eighth country, with 7.8 million diabetic patients. ${ }^{(2)}$ And it is considered the sixth most important cause of disability burden in Egypt and accounts for $1 \%$ of total deaths in Egypt. ${ }^{2,3)}$

The commonest feature of diabetes mellitus is hyperglycemia, and it causes complications as micro vascular or macro vascular complications.

(4) Control of levels of glycaemia can decrease the burden of Diabetes. ${ }^{(5)}$

The American Diabetes Association and the European Association for the Study of Diabetes identified insulin replacement therapy as a key component for effective diabetes management. ${ }^{(6)}$ Insulin can be added to either monotherapy or dual or triple therapy. ${ }^{(7)}$ Despite the proven efficacy of insulin, its initiation in patients with poor glycemic control is often delayed. ${ }^{\left({ }^{8}\right)}$ The gap between oral hypoglycemic agents' failure and start of insulin was 1.8 years in $25 \%$ of patients and almost 5 years in $50 \%$ of patients. ${ }^{(9)}$ Psychological insulin resistance (PIR) is defined as psychological opposition towards insulin use, among patients and healthcare providers and it is not a psychological disorder, but it describes a strong negative attitude towards insulin therapy. ${ }^{(10,11,12)}$

Thus, psychological insulin resistance can prevent patients from taking the insulin they need, causing hyperglycemia and put patients at 
risk of developing complications. ${ }^{(6)}$ Insulin opposition was expressed by 28-39\% in Western community and $51-70.6 \%$ by Asian studies. $(13,14,15)$ Therefore, the current study aimed to measure frequency of insulin opposition among Egyptian type 2 diabetes patients, uncontrolled, on two or more oral hypoglycemic combination therapy and to assess factors associated with insulin opposition.

\section{Methods:}

Study Design: A cross sectional study was conducted.

Study Timing: Data was collected from August till December 2017.

Study Setting: The study was conducted at Family Medicine and Diabetes outpatients Clinics at Ain Shams University Hospitals (University teaching; tertiary level hospital) in Cairo, Egypt.

Eligibility criteria for study participants: Participants attending diabetes outpatients' clinics, who met the eligibility criteria, were approached in the waiting area, and invited to participate in the study.

Inclusion Criteria: patients aged $\geq 30$ years, diagnosed as type 2 diabetes for $\geq$ one year, using two or more oral hypoglycemic agents for at least six months (The American Association of Clinical Endocrinologists (AACE) and American College of Endocrinology and (ACE) guidelines state, ${ }^{(16)}$ with Poor glycemic control; glycated hemoglobin $(\mathrm{HbA} 1 \mathrm{c}) \geq 9 \%$ in the last 6 months preceding the study time or random blood glucose performed during the week of the study timing $\geq 300-350 \mathrm{mg} / \mathrm{dL}$ (American Diabetes Association, 2016), (10) never used insulin (insulin-naive T2DM patients), ${ }^{(17)}$ and had the mental capacity to provide informed consent.

Exclusion Criteria: Type 1 diabetes patients, gestational diabetes patients, and Type 2 diabetes patients who were using insulin at the time of study.

Sample Size: The sample size was calculated based on a margin of error $5 \%$, a confidence level of $95 \%$, a width of confidence interval 0.20 and an expected proportion 0.40 , according to a previous study. (18) This would yield to 92 participants, taking into consideration the dropouts and the non-response rate estimated from the pilot study; therefore, the required sample size to achieve our study objectives was 110 diabetes patients.

Sampling Method: A purposive sample was taken from all participants attending the clinics who fulfilled the selection criteria. The sample was collected on two days per week (one day at Diabetes Clinic and one day at Family Medicine Clinic) during the working hours of the clinics.

Data Collection Tool: A pretested validated structured interview questionnaire was used. It consisted of three sections:

Section 1: socio-demographic data: Questions assessing socio-economic status were derived from socioeconomic status scale. ${ }^{(19)}$

Section 2: clinical history: Questions included data about duration of diabetes, result of $\mathrm{HbA} 1 \mathrm{C}$ within six months preceding the study time (or 
random blood sugar performed during the week of the study), history of depression, history of hypoglycemic events, presence of diabetes complications, insulin was suggested in the 6month period prior to the study, a relative took insulin, and the relative had diabetes-related complications or experienced hypoglycemia.

A dichotomous question was used to assess opposition towards insulin therapy. This singleitem measure is a validated, practical, quick, and easy screening tool to identify T2DM patients who opposed insulin initiation and it reflects a clinical reality. (20) The participants were categorized into acceptors (those who were willing to use insulin and answered "Yes") and opposers (those who were not willing to use insulin and answered "No"). ${ }^{(14)}$

\section{Section 3: perception to insulin therapy assessment: Insulin Treatment Appraisal} Scale (ITAS). ${ }^{(2)}$ The ITAS is the most used questionnaire to assess patients' appraisal of insulin treatment. It has a strong development and validation history. (20) It is a 20-item instrument that assesses positive (4) and negative (16) attitude towards insulin. Answer is given on a 5-point Likert-type scale, ranging from 'strongly disagree' to 'strongly agree' ( 0 4). No cut-off score is used to diagnose psychological insulin resistance. (22) The positive attitude subscale is calculated by adding the scores of the positive statements $(\mathrm{Q} 3, \mathrm{Q} 8$, Q17, and Q19). The score ranges from 0-16 and higher score indicates a more positive appraisal of insulin therapy. The negative subscale is calculated by adding the scores of the negative statements (all questions except the 4 positive items). The score ranges from 0-64 and a higher score indicate a more negative appraisal of insulin therapy. The total score is calculated by adding the scores of the negatively scored items and the reversed scores of the positively stated items. The total score ranges from 0 to 80 and a higher score indicates a more negative appraisal of insulin therapy.

Concerns towards insulin therapy: Some items which were not included in the ITAS were selected from previous studies and added. ${ }^{(12,23)}$

The questionnaire was translated into Arabic and translated back into English. Discrepancies between the original English items and backtranslated items were reviewed. A pilot test was performed on 30 participants with Type 2diabetes to check for the clarity of the questionnaire then some items were modified to enhance their clarity.

Data Management and Analysis: were managed with Statistical Package for Social Sciences (SPSS) version 20 for windows. Data were checked for accuracy of data entry and missing values. Data were summarized by count and percentage for categorical data; and mean $\underline{ \pm}$ standard deviation for continuous data. Statistical inference was drawn using independent $t$ test for quantitative variable and Chi-square for qualitative variable analysis. A value of $\mathrm{p} \leq 0.05$ was considered significant. A multivariable logistic regression analysis was performed to evaluate the association between opposition to 
start insulin therapy and participant characteristics. Selected variables were inserted by Enter method. The logistic regression model was statistically significant $\left(\mathrm{p}=0.001^{*}\right)$. The model explained $48.4 \%$ (NagelkerkeR ${ }^{2}$ ) of the variance of insulin opposition and correctly classified $79.2 \%$ of cases, with Hosmer and Lemshow test significance 0.834 .

Ethical considerations: Verbal informed consent was obtained as data were collected through data collection sheets only and there was no invasive procedure done to participants. Confidentiality of data was assured by anonymity of the questionnaire.

\section{Results:}

Among 103 participants, about 52.4\% were female, and mean age was $54 \pm 9.3$ years. Mean duration of diabetes was $10.3 \pm 6.6$, mean $\mathrm{HbA} 1 \mathrm{C}$ was $10.0 \pm 1.3$, and mean random blood glucose level was $355.3 \pm 67.4$. More than half of the participants had T2DM relatives who use insulin, experienced hypoglycemic events which required medical attention in the period of six months preceding the study timing and previously advised by their physicians to start insulin in the period of six months preceding the study timing as shown in Table 1.

There was a statistically significant difference between opposers and acceptors regarding having insulin using T2DM relatives, experienced previous hypoglycemic events, and previous physician's recommendation to start insulin therapy where insulin opposition was less common as shown in Table 2.
Agreement with individual Insulin Treatment Appraisal Scale (ITAS) items and Concerns towards insulin therapy compared between oppose and acceptor participants as seen in Figures $1 \& 2$.

ITAS total score and its subscales, opposers reported significantly higher mean total score and its subscales compared to acceptors as shown in Table 3.

A logistic regression was performed to ascertain the effects of duration of diabetes, family history of insulin using T2DM relatives, physicians' recommendations, history of hypoglycemic events, ITAS total score, concern about insulin being a lifelong therapy and delaying insulin until no alternatives on the likelihood that participants have insulin opposition with age and gender adjustment. Significant variables in the model were physicians' recommendations, concern about insulin being a lifelong therapy and ITAS score; therefore, these factors considered as risk factors for insulin opposition. Patients who were concerned about insulin being a lifelong therapy were 12 times more opposing to start insulin than patients without this concern. Patients with previous physicians' recommendation on insulin were 6 times more accepting to start insulin therapy than patients without doctor recommendation. An increase by one unit in ITAS total score increased insulin opposition by 1.1 times as shown in Table 4. 


\section{Discussion:}

The frequency of opposition to start insulin $(55.3 \%)$ in the current study is higher than that reported among insulin naive T2DM participants in Saudi Arabia (34.6\%), ${ }^{(23)}$ Amsterdam (39\%), ${ }^{(13)}$ China (47.2\%), ${ }^{(24)}$ and USA $(33 \%) .{ }^{(25)}$ Also, it is higher than estimated frequency $(40 \%)$ in previous study at an outpatient clinic in Egypt. ${ }^{(18)}$ This discrepancy can be attributed to the difference in the applied method to diagnose insulin opposition.

The study of El Shafei et al. (2015) depended on a cutoff point on Insulin Treatment Appraisal Scale (ITAS) to diagnose insulin opposition, while the current study used a validated, single-item measure, asking if the participant agrees to start insulin, which reflects the clinical reality that a participant is either willing or not. ${ }^{(26)}$ Some studies revealed that patients were more likely to oppose insulin initiation when they are faced with their poor glycemic control, ${ }^{(15)}$ which reflects their diabetes severity. ${ }^{(12)}$

However, it was lower than that reported in Libya $\quad(94.6 \%),{ }^{(27)}$ Malaysia $(74.2 \%),{ }^{(30)}$ Singapore $(70.6 \%),{ }^{(14)}$ and Pakistan $(65 \%) .{ }^{(31)}$ Variation among countries in prevalence of insulin opposition may explained by either diversity in beliefs and attitudes towards insulin which affected by difference in cultures between countries or difference in health care systems as access to medications and regular follow ups.

There was no statistically significant relation between age and insulin opposition.
Yet, it is worth mentioning that more insulin opposition was observed in younger age. This agrees with a previous study among insulin naïve T2DM patients in Libya, ${ }^{(27)}$ Saudi Arabia, (23) Iran, (29) Malaysia, ${ }^{(30)}$ and Amsterdam. ${ }^{(13)}$ This can be explained by younger aged patients think that oral therapy needs some time to act or fear from insulin complication. In contrary, a previous study in Egypt observed more insulin opposition in older patients. ${ }^{(18)}$

There was no statistically significant relation between gender and insulin opposition. This can be attributed to the sample being equally distributed between both genders. Similarly, same finding was found in previous studies in Egypt, ${ }^{(18)}$ Libya, ${ }^{(27)}$ and China. ${ }^{(24)}$ In contrary, in Malaysia, female were 2.7 times more likely to resist insulin treatment compared to male. ${ }^{(15)}$ However, in a study in Saudi Arabia, female participants were significantly more accepting to start insulin therapy. It was attributed to cultural reasons, where females might be more compliant with medical advice and trust their treating physicians. ${ }^{(23)}$

There was no statistically significant relation between educational level and insulin opposition. Yet, it is worth mentioning that among participants with no formal education, acceptance of insulin was more common than opposition. This is in line with a previous study in Saudi Arabia, where participants with tertiary education were more likely to refuse insulin initiation, while those with less education were more likely to agree to start insulin. ${ }^{(23)}$ 
A possible reason may be that participants with lower educational level may have more trust in their healthcare care professional's advice and compliance to start insulin. This is inconsistent with previous studies reported that participants with higher level of education were more accepting to start insulin in Egypt, ${ }^{(18)}$ Malaysia, (30) and Pakistan. $^{(31)}$

There was a statistically significant relation between the duration of diabetes and insulin opposition, where longer duration of diabetes was significantly associated with less insulin opposition; this relation can be attributed to that longer duration of diabetes is usually associated with much poorer glycemic control and more diabetes complications, thus might show more confidence in insulin therapy, and less opposition to start it. In opposite, a previous study in Egypt reported that longer duration of diabetes was associated with more insulin opposition. $^{(18)}$

There was a statistically significant relation between family history of insulin use and insulin opposition. Among participants with insulinusing relatives, more than half $(55.6 \%)$ accepted to start insulin, compared to $44.4 \%$ who opposed insulin initiation, with $\mathrm{P}=0.02$. This implies that having insulin using relatives is associated with less opposition to insulin initiation. A possible explanation that patients may indirectly learn from the experiences of relatives and thus have a clearer understanding of the nature of insulin use. There was a statistically significant relation between physicians' advice on insulin and insulin opposition with participants who received physicians' advice on insulin were 6 times more accepting to start insulin therapy than those who did not receive any advice on insulin. A possible explanation can be that patients who received physician's advice may have a clearer understanding of insulin and less concerned about injection techniques and more convinced with benefits of insulin. Likewise, a systematic review previously documented that positive experience of others and support from healthcare providers may facilitate insulin initiation. ${ }^{(32)}$

There was a statistically significant relation between previous hypoglycemic events requiring medical attention and insulin opposition. Among participants who were exposed to previous hypoglycemic events, more than half $(54.1 \%)$ accepted to start insulin therapy. This implies that exposure to hypoglycemia was associated with less insulin opposition and the explanation may be that previous exposure to hypoglycemia might have decreased patients' satisfaction with oral treatment and encouraged them to accept new treatment options like insulin. In contrary, a study in Amsterdam among insulin naïve T2DM patients, suggested that previous exposure to hypoglycemic events increased opposition towards insulin therapy. ${ }^{(13)}$

Generally, both positive and negative beliefs about insulin are the basis of patients' decision to initiate insulin. ${ }^{(33)}$ In the current study, 
opposers reported more negative and fewer positive beliefs than acceptors.

Regarding Insulin Treatment Appraisal Scale (ITAS) items, opposer were significantly higher than acceptor in sense of that Taking insulin means failure to manage diabetes, taking insulin means diabetes worse, taking insulin makes life less flexible, and managing insulin injections takes a lot of time and energy. Similar findings about failure to manage diabetes and diabetes worse were reported in previous studies in Egypt, ${ }^{(18)}$ and Malaysia. ${ }^{(15)}$ While similar findings about concern of taking insulin makes life less flexible were found in previous studies conducted in Saudi Arabia, ${ }^{(23)}$ Malaysia, ${ }^{(15)}$ USA. ${ }^{(25)}$

About belief that taking insulin makes life less flexible was reported more frequent in a study in USA, ${ }^{(25)}$ and in a systematic review explained that participants in many studies elsewhere viewed insulin treatment as inconvenient because they must carry insulin pen with them and inject regularly. ${ }^{(32)}$

Regarding ITAS score, there was a statistically significant difference between opposers and acceptors regarding the mean of total score, positive and negative subscales. Also, total ITAS score was one of the significant variables associated with insulin opposition, where increase by one unit in the total score increased insulin opposition by 1.1. This was also found in other studies using ITAS tool in Egypt,${ }^{(18)}$ China, ${ }^{(24)}$ Amsterdam,,${ }^{(13)}$ USA, ${ }^{(25)}$ and Britain. $^{(28)}$ Opposers were significantly higher than acceptor in their concern that insulin cause health problems, better to delay insulin until there are no alternative, and insulin being a lifelong therapy. Similar findings about insulin cause health problems were reported by $\mathrm{El}$ Shafei et al., 2015 in Egypt, ${ }^{(18)}$ Malaysian, ${ }^{(30)}$ and Singaporean patients. ${ }^{(14)}$

This mistaken belief may be due to patients may relate complications of diabetes such as renal failure and blindness to insulin use rather than insufficient glycemic control. About the concern of Delaying insulin until no other alternatives, similar results were reported among patients in Saudi Arabia, ${ }^{(23)}$ Turkey, ${ }^{(21)}$ and in a study among five countries (Germany, Sweden, Netherlands, UK and USA). ${ }^{(12)}$

This may be attributed to the delay of insulin initiation by healthcare providers, which disseminates the idea that insulin is a last resort and should only be used when the disease is severe. Concern about insulin being a lifelong therapy, similar finding was reported in Egypt, ${ }^{(18)}$ and Amsterdam. ${ }^{(13)}$

Study Limitations: Other important contributors to insulin delay were not assessed in this study as healthcare providers' barriers, patients' religious, cultural beliefs, and use of herbal medications. therefore, further studies should be conducted on these factors. Also, patients were not followed longitudinally to assess beliefs and attitudes towards insulin after insulin initiation. Therefore, further studies should be conducted to study the effect of other contributors and to assess the change in beliefs 
and attitudes towards insulin after insulin initiation.

Conclusion: In type 2 diabetic uncontrolled patients, psychological insulin opposition is common and that will lead to unnecessarily long delay in initiating insulin therapy and consequently to extended periods of hyperglycemia. There is more than one concern against insulin initiation.

Recommendations: Increasing physicians' awareness about factors affecting insulin opposition through comprehensive training sessions is important to improve the strategy for identifying and reducing insulin opposition among patients.

Acknowledgment: To all the study participants who participated in this work.

Fund: The research was conducted with no fund.

Conflict of Interest: There was no conflict of interest as well.

\section{References}

1. International Diabetes Federation. IDF diabetes atlas. 7th ed. Brussels: International Diabetes Federation; 2015. Available from: http:// www.diabetesatlas.org (accessed at: January 21, 2019).

2. World Health Organization. Global report on diabetes. Geneva, Switzerland; 2016. Available from: https://apps.who.int/iris/handle/10665/2048 71 (accessed at: July 10, 2019).

3. Herman WH, Ali MA, Aubert RE, Engelgau MM, Kenny SJ, Gunter EW, et al. Diabetes mellitus in Egypt: Risk factors and prevalence. Diabet Med. 1995; 12:1126-31.

4. Stolar M. Glycemic control and complications in type 2 diabetes mellitus. Am J Med. 2010; 123(3): S3-11.

5. Holman N, Young B, Gadsby R. Current prevalence of type 1 and type 2 diabetes in adults and children in the UK. Diabet Med. $2015 ; 32: 1119-20$.

6. Nathan DM, Buse JB, Davidson MB, Ferrannini E, Holman RR, Sherwin R, et al. Medical management of hyperglycemia in type 2 diabetes: a consensus algorithm for the initiation and adjustment of therapy: a consensus statement from the American Diabetes Association and the European Association for the Study of Diabetes. Diabetes Care. 2009; 32: 193-203

7. American Diabetes Association. Approaches to glycemic treatment. Sec. 7. In Standards of Medical Care in Diabetes-2016. Diabetes Care. 2016; 39(Suppl. 1): S52-9

8. Hayes RP, Fitzgerald JT. Jacober SJ. Primary care physician beliefs about insulin initiation in patients with type 2 diabetes. Int J Clin Pract. 2008; 62(6):860-8.

9. Rubino A, McQuay LJ, Gough SC, Kvasz M, Tennis P. Delayed initiation of subcutaneous insulin therapy after failure of oral glucoselowering agents in patients with Type 2 diabetes: a population-based analysis in the UK. Diabet Med. 2007; 24(12):1412-8.

10. Peyrot M, Rubin RR, Khunti K. Addressing barriers to initiation of insulin in patients 
with type 2 diabetes. Prim Care Diabetes. 2010; 4: S11-8.

11. Gherman A, Veresiu IA, Sassu RA, Schnur JB, Scheckner BL, Montgomery GH. Psychological insulin resistance: a critical review of the literature. Pract Diabetes Int. 2011; 28(3):125-128.

12. Brod M, Kongsø JH, Lessard S, Christensen TL. Psychological insulin resistance: patient beliefs and implications for diabetes management. Qual Life Res. 2009; 18(1):23-32.

13. Woudenberg YJ, Lucas C, Latour C, Scholte op Reimer WJ. Acceptance of insulin therapy: a long shot? Psychological insulin resistance in primary care. Diabet Med. 2012, 29(6):796-802.

14. Wong S, Lee J, Ko Y, Chong MF, Lam CK, Tang WE. Perceptions of insulin therapy amongst Asian patients with diabetes in Singapore. Diabet Med. 2011; 28(2):206-11.

15. Nur Azmiah Z, Zulkarnain AK, Tahir A. Psychological insulin resistance (PIR) among type 2 diabetes patients at public health clinics in federal territory of Malaysia. Int Med J Malaysia. 2011; 10(2):7-12.

16. Garber AJ, Abrahamson MJ, Barzilay JI, Blonde L, Bloomgarden ZT, Bush MA, et al. Consensus statement by the American Association of Clinical Endocrinologists and American College of Endocrinology on the comprehensive type 2 diabetes management algorithm-2016 executive summary. Endocr Pract. 2016; 22(1):84113.

17. Koopmans B, Pouwer F, de Bie RA, Leusink GL, Denollet JKL, Pop VJM. Associations between vascular comorbidities and depression in insulin-naive diabetes patients: the DIAZOB Primary Care Diabetes study. Diabetologia. 2009; 52(10):2056-63.

18. El Shafei MM, Sayyah HE, Hussein R. Psychological insulin resistance in patients with type 2 diabetes mellitus. Egypt J Psychiatry. 2015; 36:60-5

19. El-Gilany A, El-Wehady A, El-Wasify M. Updating and validation of the socioeconomic status scale for health research in Egypt. East Mediterr Health J. 2012 Sep; 18(9):962-8.

20. Holmes-Truscott E, Pouwer F, Speight J. Assessing psychological insulin resistance in type 2 diabetes: a critical comparison of measures. Curr Diab Rep. 2017; 17(7):46.

21. Yilmaz A, Ak M, Cim A, Palanci Y, Kilinc F. Factors influencing insulin usage among type 2 diabetes mellitus patients: A study in Turkish primary care. Eur J Gen Pract. 2016; 22(4):255-61.

22. Snoek FJ, Skovlund SE, Pouwer F. Development and validation of the insulin treatment appraisal scale (ITAS) in patients with type 2 diabetes. Health Qual Life Outcomes. 2007; 5: 69-75.

23. Batais MA, Schantter P. Prevalence of unwillingness to use insulin therapy and its 
associated attitudes amongst patients with Type 2 diabetes in Saudi Arabia. Prim Care Diabetes. 2016; 10(6):415-24.

24. Lee KP. Psychosocial factors associated with psychological insulin resistance in primary care patients in Hong Kong. J Clin Transl Endocrinol. 2015; 2(4):157-62.

25. Larkin ME, Capasso VA, Chen CL, Mahoney EK, Hazard B, Cagliero E, et al. Measuring psychological insulin resistance: barriers to insulin use. Diabetes Educ. 2008; 34(3):511-7.

26. Holmes-Truscott E, Pouwer F, Speight J. Assessing psychological insulin resistance in type 2 diabetes: a critical comparison of measures. Curr Diab Rep. 2017; 17(7):46.

27. Sabei LT, Sammud M. Attitude towards Insulin Therapy among Patients with Type 2 Diabetes in Tripoli, Libya. Ibnosina Journal of Medicine and Biomedical Sciences. 2015; 7(4):127-35.

28. Taylor Jr CG, Taylor G, Atherley A, Hambleton I, Unwin N, Adams OP. The Barbados Insulin Matters (BIM) study: Barriers to insulin therapy among a population-based sample of people with type 2 diabetes in the Caribbean island of Barbados. J Clin Transl Endocrinol. 2017; $8: 49-53$.

29. Ghadiri-Anari A, Fazaelipoor Z, Mohammadi SM. Insulin refusal in Iranian patients with poorly controlled type 2 diabetes mellitus. Acta Med Iran. 2013; 51(8):567.
30. Tan WL, Asahar SF, Harun NL. Insulin therapy refusal among type II diabetes mellitus patients in Kubang Pasu district, Kedah, Malaysia. Singapore Med J. 2015; 56(4):224.

31. Saleem A, Masood I, Khan TM. Insulin perception among insulin-naïve type-2 diabetes mellitus patients in Pakistan. Cogent Med. 2016; 3: 1, 1229374.

32. Ng CJ, Lai PS, Lee YK, Azmi SA, Teo CH. Barriers and facilitators to starting insulin in patients with type 2 diabetes: a systematic review. Int J Clin Pract. 2015; 69(10):105070.

33. Hassan HA, Tohid H, Amin RM, Bidin MBL., Muthupalaniappen L, Omar K. Factors influencing insulin acceptance among type 2 diabetes mellitus patients in a primary care clinic: a qualitative exploration. BMC Fam Pract. 2013; 14(1):164. 
Table (1): Characteristics of Diabetic Patients Attending Outpatient Clinic at Ain Shams University Hospital

\begin{tabular}{|c|c|c|}
\hline 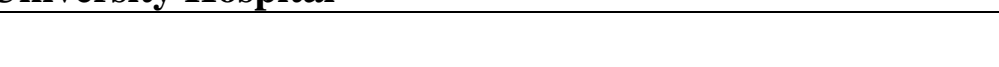 & $\mathbf{N}$ & $\%$ \\
\hline Age $($ Mean \pm SD $)($ Min - Max $)$ & \multicolumn{2}{|c|}{$54.2 \pm 9.3(35.0-76.0)$} \\
\hline \multicolumn{3}{|l|}{ Gender } \\
\hline - Male & 49 & $47.6 \%$ \\
\hline - Female & 54 & $52.4 \%$ \\
\hline \multicolumn{3}{|l|}{ Marital status } \\
\hline - Married & 83 & $80.6 \%$ \\
\hline - Unmarried & 20 & $19.4 \%$ \\
\hline \multicolumn{3}{|l|}{ Educational level } \\
\hline - No formal education & 35 & $34 \%$ \\
\hline - $\quad$ Primary / preparatory & 14 & $13.6 \%$ \\
\hline - Secondary & 3 & $2.9 \%$ \\
\hline - Intermediate institutes & 25 & $24.3 \%$ \\
\hline - University graduate & 26 & $25.2 \%$ \\
\hline \multicolumn{3}{|l|}{ Occupational status } \\
\hline - Non-working/housewife & 55 & $53.4 \%$ \\
\hline - Working & 48 & $46.6 \%$ \\
\hline Duration of diabetes (years) $($ Mean \pm SD) $($ Min - Max $)$ & \multicolumn{2}{|c|}{$10.3 \pm 6.6(1.0-35.0)$} \\
\hline last HbA1C (Mean \pm SD) (Min - Max $)$ & \multicolumn{2}{|c|}{$10.0 \pm 1.3(9.0-14.0)$} \\
\hline blood glucose level $($ Mean \pm SD) $($ Min - Max $)$ & \multicolumn{2}{|c|}{$355.3 \pm 67.4(300.0-600.0)$} \\
\hline T2DM relatives using insulin & 54 & $52.4 \%$ \\
\hline History of hypoglycemic events & 61 & $59.2 \%$ \\
\hline Previous physician's recommendation on insulin & 54 & $52.4 \%$ \\
\hline \multicolumn{3}{|l|}{ Agree to start insulin therapy? } \\
\hline - Opposer & 57 & $55.3 \%$ \\
\hline - Acceptor & 46 & $44.7 \%$ \\
\hline
\end{tabular}


Table (2): Diabetic Patients' Characteristics by Opposition to Use Insulin

\begin{tabular}{|c|c|c|c|c|c|c|}
\hline \multirow{5}{*}{$\begin{array}{l} \\
\text { Age }(\text { Mean } \pm \text { SD }) \\
\text { Gender }\end{array}$} & \multicolumn{4}{|c|}{ Insulin opposition } & \multirow[t]{3}{*}{ Test } & \multirow[t]{3}{*}{$\mathbf{P}$} \\
\hline & \multicolumn{2}{|c|}{$\begin{array}{l}\text { Opposer } \\
(57)\end{array}$} & \multicolumn{2}{|c|}{$\begin{array}{l}\text { Acceptor } \\
\text { (46) }\end{array}$} & & \\
\hline & $\mathbf{N}$ & $\%$ & $\mathbf{N}$ & $\%$ & & \\
\hline & \multicolumn{2}{|c|}{$52.9 \pm 9.1$} & \multicolumn{2}{|c|}{$55.2 \pm 9.5$} & $1.243^{\#}$ & .217 \\
\hline & & & & & & \\
\hline - Male & $\begin{array}{l}3 \\
0\end{array}$ & $\begin{array}{l}61.2 \\
\%\end{array}$ & $\begin{array}{l}1 \\
9\end{array}$ & $\begin{array}{l}38.8 \\
\%\end{array}$ & \multirow[t]{2}{*}{$1.310^{\dagger}$} & \multirow[t]{2}{*}{.252} \\
\hline - Female & $\begin{array}{l}2 \\
7\end{array}$ & $50 \%$ & $\begin{array}{l}2 \\
7\end{array}$ & $50 \%$ & & \\
\hline \multicolumn{7}{|l|}{ Educational level } \\
\hline - No formal education & $\begin{array}{l}1 \\
4\end{array}$ & $\begin{array}{l}41.5 \\
\%\end{array}$ & $\begin{array}{l}2 \\
0\end{array}$ & $\begin{array}{l}58.8 \\
\%\end{array}$ & 4.495 & .213 \\
\hline - Primary/ preparatory & $\begin{array}{l}1 \\
1\end{array}$ & $\begin{array}{l}73.3 \\
\%\end{array}$ & 4 & $\begin{array}{l}26.7 \\
\%\end{array}$ & & \\
\hline - $\quad$ Secondary & 3 & $100 \%$ & 0 & $0 \%$ & & \\
\hline - Intermediate institute & $\begin{array}{l}1 \\
5\end{array}$ & $60 \%$ & $\begin{array}{l}1 \\
0\end{array}$ & $40 \%$ & & \\
\hline - University graduate & $\begin{array}{l}1 \\
4\end{array}$ & $\begin{array}{l}53.8 \\
\%\end{array}$ & $\begin{array}{l}1 \\
2\end{array}$ & $\begin{array}{l}46.2 \\
\%\end{array}$ & & \\
\hline Duration of Diabetes (Mean \pm SD) & \multicolumn{2}{|c|}{$8.4 \pm 5.1$} & \multicolumn{2}{|c|}{$12.5 \pm 7.4$} & $3.201^{\#}$ & $\begin{array}{l}.002 \\
*\end{array}$ \\
\hline HbA1C (Mean \pm SD) & \multicolumn{2}{|c|}{$9.8 \pm 1.3$} & \multicolumn{2}{|c|}{$10.1 \pm 1.3$} & $0.457^{\#}$ & .652 \\
\hline Blood glucose level (Mean \pm SD) & \multicolumn{2}{|c|}{$364 \pm 75.7$} & \multicolumn{2}{|c|}{$346 \pm 57.1$} & $0.979^{\#}$ & .332 \\
\hline T2DM relatives using insulin & $\begin{array}{l}2 \\
4\end{array}$ & $44.4 \%$ & $\begin{array}{l}3 \\
0\end{array}$ & 55.6 & $5.452^{\dagger}$ & $\begin{array}{l}.020 \\
*\end{array}$ \\
\hline Diabetes related complications & $\begin{array}{l}4 \\
0\end{array}$ & $\begin{array}{l}51.9 \\
\%\end{array}$ & $\begin{array}{l}3 \\
7\end{array}$ & $\begin{array}{l}48.1 \\
\%\end{array}$ & $1.420^{\dagger}$ & .233 \\
\hline History of hypoglycemic events & $\begin{array}{l}2 \\
8\end{array}$ & $45.9 \%$ & $\begin{array}{l}3 \\
3\end{array}$ & $54.1 \%$ & $5.392^{\dagger}$ & .020 \\
\hline $\begin{array}{l}\text { Previous physician's } \\
\text { recommendation on insulin }\end{array}$ & $\begin{array}{l}2 \\
0\end{array}$ & $37 \%$ & $\begin{array}{l}3 \\
4\end{array}$ & $63 \%$ & 15.385 & $\begin{array}{l}.000 \\
*\end{array}$ \\
\hline
\end{tabular}

$(\dagger)$ Chi Square test, (\#) Independent t-test, (*) $\mathrm{P}$ value $\leq 0.05$ is considered statistically significant Difference. 
Table 3. Relation Between Opposition to Initiate Insulin and Insulin Therapy Appraisal Scale (ITAS) Scores Among Study Participants.

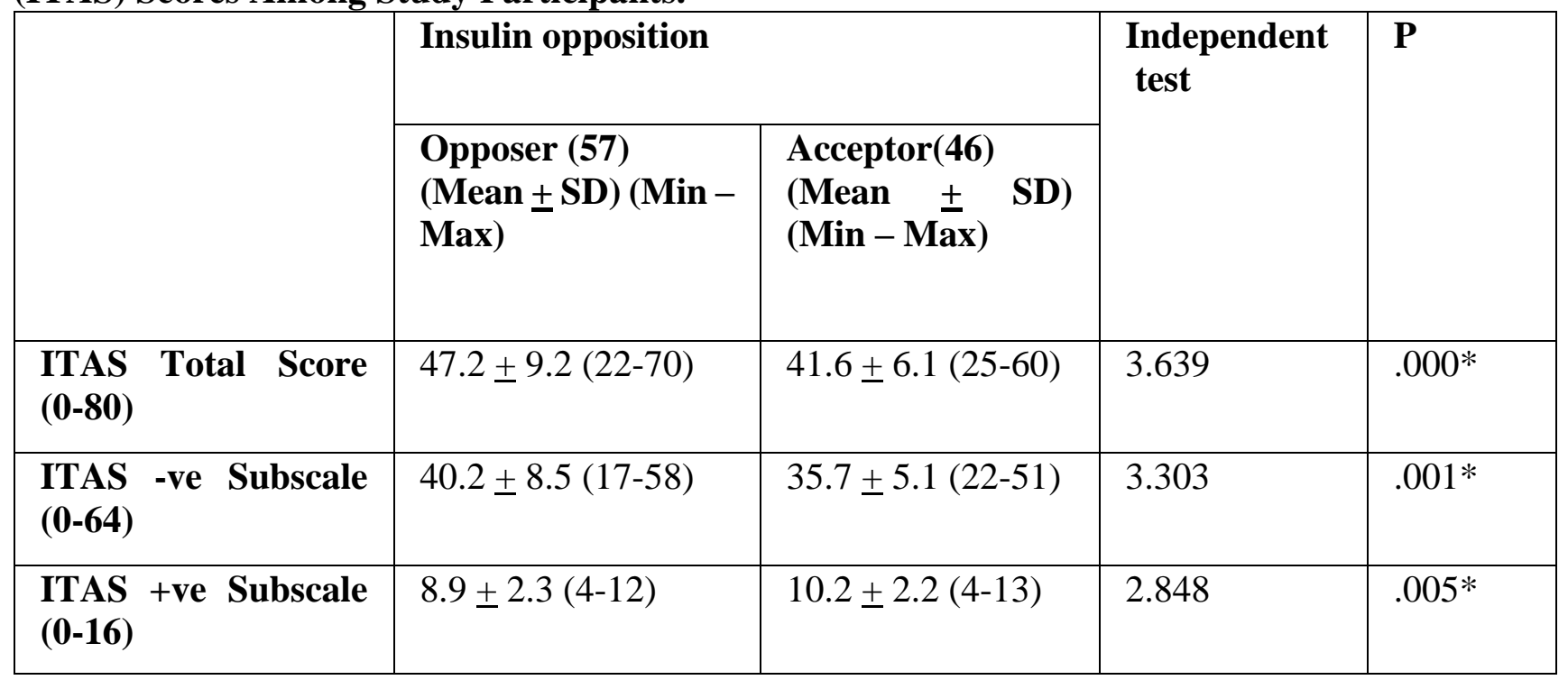

(*) $\mathrm{P}$ value $\leq 0.05$ is considered statistically significant

Table (4): Logistic Regression Between Opposition to Start Insulin Therapy and Other Variables with Adjustment Of Age And Gender

\begin{tabular}{|l|l|l|l|l|}
\hline & B & P & OR & $\begin{array}{l}\text { 95\% CI } \\
\text { (upper limit- lower limit) }\end{array}$ \\
\hline Age & -0.026 & 0.359 & 0.974 & $(0.921-1.030)$ \\
\hline Gender & -0.613 & 0.271 & 0.542 & $(0.182-1.615)$ \\
\hline Physicians recommendations (absent) & 1.861 & $0.001^{*}$ & 6.428 & $(2.104-19.642)$ \\
\hline $\begin{array}{l}\text { Concern about insulin being a lifelong } \\
\text { therapy }\end{array}$ & 2.518 & $0.000^{*}$ & 12.407 & $(3.419-45.026)$ \\
\hline ITAS Total Score (0-80) & 0.104 & $0.004 *$ & 1.110 & $(1.034-1.191)$ \\
\hline Constant & -4.594 & 0.043 & 0.010 & \\
\hline
\end{tabular}

(*) $\mathrm{P}$ value $\leq 0.05$ is considered statistically significant 


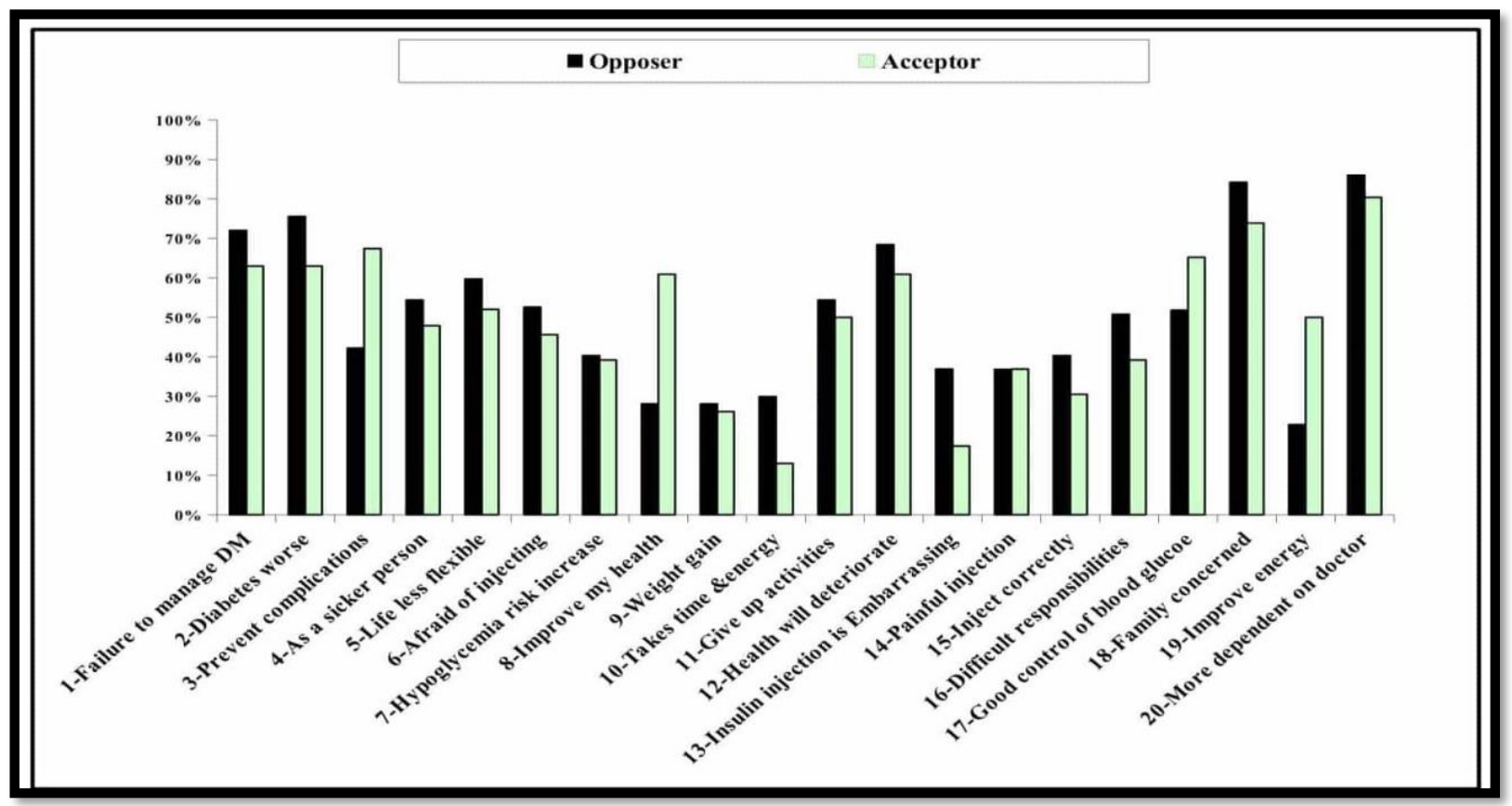

Figure (1): Agreement with individual Insulin Treatment Appraisal Scale (ITAS) items compared between oppose and acceptor participants

Data are percentages of participants who agreed ('agree' or 'strongly agree') with each item. ${ }^{*} \mathrm{P} \leq 0.05$ : sense of failure, diabetes worse, prevent complication, life less flexible, helps to improve health, takes time and energy, and improve energy.

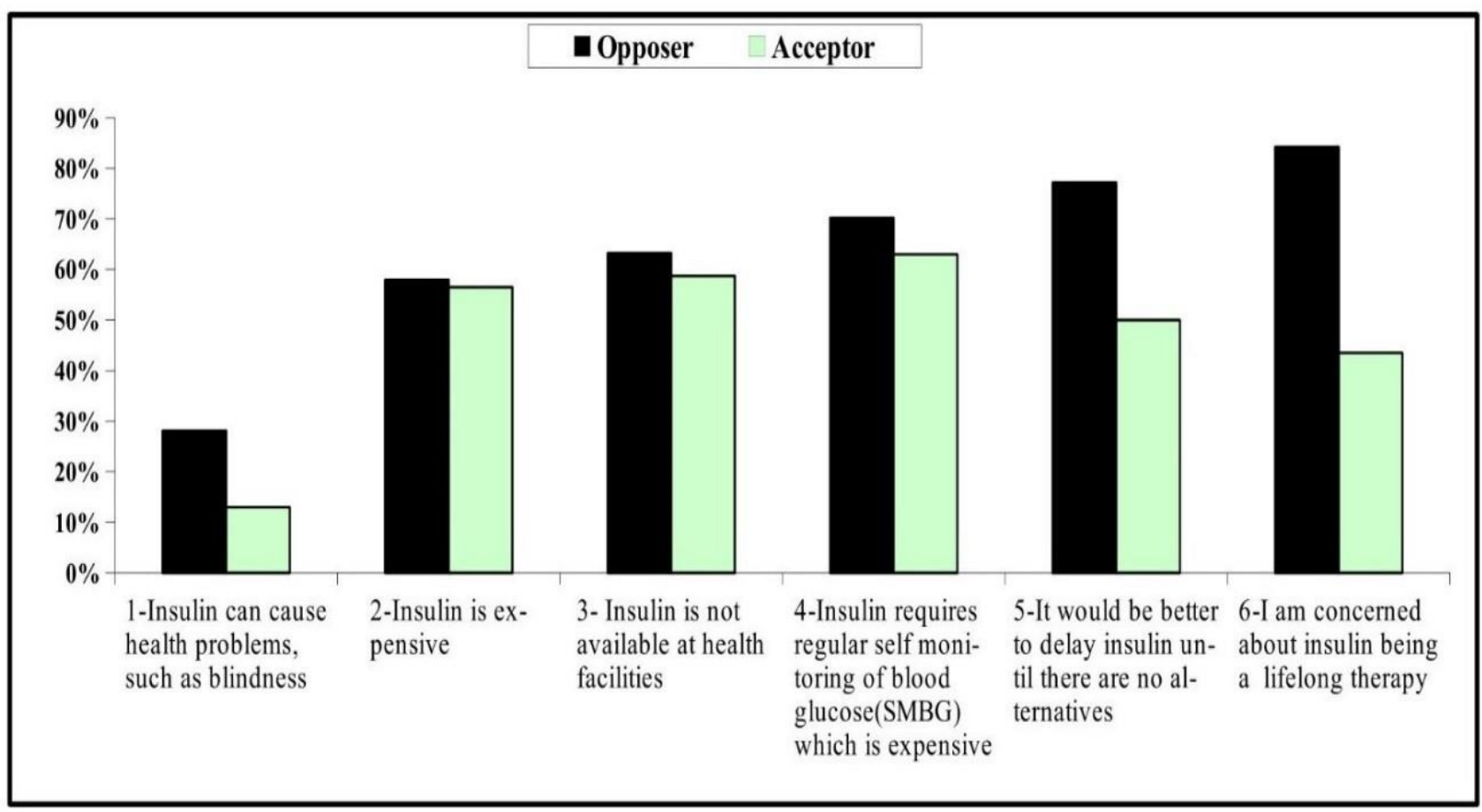

Figure (2): Concerns towards insulin therapy among the studied population compared between oppose and acceptor participants

Data are percentages of participants who agreed ('agree' or 'strongly agree') with each item. 


\section{الملخص العربي}

\section{العوامل التي تؤثر على معارضة باء الأنسولين بين مرضى داء السكرى من النوع الثانى في مستثفيات جامعة عين شمس شرطى داع}

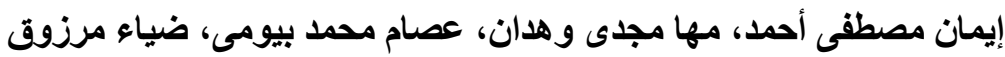

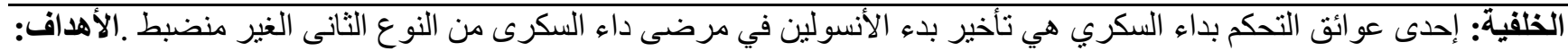
قياس معدل معار ضنة الأنسولين بين المصريين المصابين بداء السكري من النوع الثانى الغير منضبط ، و على نو عين أو أكثر من العلاج المركب ، وتحديد العو امل المرتبطة بمعارضنهم للأنسولين.الطريقة: تم أجراء دراسة مقطعية في عبادات المرضى الخارجيين في مستشفيات جامعة عين شمس ، على عينة عشو ائية من 103 مريض بداء السكري من النوع الثانى الغير منضبطو و على نوعين أو أكثر من العلاج المركب ، و ذللك باستخدام استبيان منظم. النتائج: و قد بلغت نسبة المرضى بداء السكرى الغير منضبطو الذين يعارضون بدء الأنسولين 55.3 ٪. وقد كانت أكثر المو اقف السلبية الأكثر شيوعًا والتي تختلف أختلافا كبير ا بين المعارضين والمتقلين للأنسولين: أعنبار الأنسولين كملاذ أخبر (77.2٪ مقابل 50٪) ، وشدة داء السكري المدركة (75.4٪ مقابل 63\%) ، مخاوف بشأن مرونة أقل (59.6٪ مقابل 52.2\%) ، الوقت و الجهد مع حقن الأنسولين (29.8٪ مقابل 13\%) و الضرر المتوقع من الأنسولين (28.1\% مقابل 13\%). و قد كان المعارضين أقل اتفاقا على العناصر الإيجابية المتعلقة بدور الأنسولين في تحسين مستوى الطاقة (22.8٪ مقابل 50٪) ، وتحسين الصحة (28.1\% مقابل 60.9٪) و الوقاية من مضاعفات داء السكري (42.1\% مقابل 67.4\%) .الخلاصة و التوصيات: أرتفاع معدل معارضة الأنسولين و العو امل المرتبطة به بين مرضى داء السكرى من النوع الثنانى الغير منضبط؛ وبالتالي ، الحاجة إلى زيادة

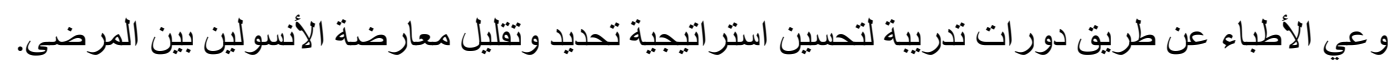

